\title{
Addition to Special Issue "Fate and effects of the residues of anticancer drugs in the environment"
}

Published online: 5 July 2016

(C) Springer-Verlag Berlin Heidelberg 2016

The following article is a contribution to this Special Issue "Fate and effects of the residues of anticancer drugs in the environment" but was erroreously published in:

Environmental Science and Pollution Research

June 2016, Volume 23, Issue 11, pp 11209-11223

DOI 10.1007/s11356-016-6321-1

Human metabolites and transformation products of cyclophosphamide and ifosfamide: analysis, occurrence and formation during abiotic treatments

Marjeta Česen • Tina Kosjek • Francesco Busetti - Boris Kompare $\cdot$ Ester Heath

Received: 12 October 2015/Accepted: 16 February 2016/ Published online: 27 February 2016 